\title{
Danish Centre for Museum Research: New modes of collaboration and quality development
}

\author{
Hans Dam Christensen* and Kirsten Drotner*
}

\begin{abstract}
In August 2011, Danish Centre for Museum Research (DCMR) was established as a national research centre without walls. Members are Danish university departments that have museum research as a key research area, and the Centre currently lists 14 members spanning almost all universities. DCMR defines museum research in inclusive terms, embracing research on museums, archives, activity and experience centres and encompassing art, cultural and natural heritage in its tangible as well as intangible modes of articulation. The overall aim of the Centre is to advance the quantity and quality of Danish museum research and practice based on the scientific insights and resources originating from Danish universities and their Nordic and wider international research networks.
\end{abstract}

Key words: Danish Centre for Museum Research, museum research, research communication, knowledge exchange.

WHY DID WE START?

In concrete terms, DCMR was founded as a response to university researchers' experience of our field, namely that it is often based on individual scholars' insights, networks and interactions and therefore it can be difficult to set up substantive and organisational continuity and visibility in the field. So, DCMR has been established to serve as a robust organisational base for the advancement of universities' museum research.

Moreover, while university researchers have easy and systematic access to most Danish museums and the research found there via the national Association of Danish Museums (Organisationen Danske Museer), museums interested in collaborating with Danish university researchers hitherto had no similar 'front door' for easy access and systematic overview of who does what; and hence they developed ad hoc and personal contacts rather than sustained organisational ties. So, DCMR is meant as a visible entry point for universities' museum research, welcoming museum colleagues as well as other partners.

In wider terms, the formation of DCMR may be seen as an organisational response to the situation found in public sector universities and museums in many parts of the world. 
126 These organisations currently find themselves straddling discourses of enlightenment for the general public and discourses of marketisation for industry advancement (Nowotny, Scott \& Gibbons 2001, Skot-Hansen 2008, Drotner \& Schrøder 2013); and so many attempt to handle these often divisive discourses by forging new modes of knowledge formation and exchange. Both at universities and at many museums research is being reorganised across boundaries of disciplinary domains and geographical locations. DCMR is one way to facilitate that such potential reorganisations are founded on a solid, scientific knowledge base.

\section{WHAT DO WE DO?}

As noted, the overall aim of DCMR is to advance the quantity and quality of Danish university-based museum research. This aim materialises itself in strategic priorities to coordinate existing research activities across institutional boundaries in order to optimise financial and human resources; to initiate research activities on a national and wider international scale in order to further scientific innovation; and to illuminate research results in order to strengthen networking and knowledge exchange with museum stakeholders and policy makers.

One of the first centre initiatives has been to survey existing university-based museum research in Denmark: what are its substantive focal points? How is it organised and funded? What are the researchers' career profiles? The resulting report Dansk museumsforskning: status og tendenser [Danish museum research: status and trends] (Villadsen \& Drotner 2012) offers a first profile of existing trends in Danish university-based museum research, the most important of which confirm some of the key assumptions underlying the formation of DCMR: current research is overwhelmingly dependent on individual initiatives and engagements, and more than half of ongoing projects are carried out by master or $\mathrm{PhD}$ students, thus making for volatile and shifting research agendas. Two-thirds of projects in the study comprise several researchers, and funding is primarily tied to personal grants rather than to major projects or research centres. As for thematic priorities, museum communication takes up more than half of all projects, while few researchers focus on areas such as acquisition, archiving and organisation. Very importantly, most projects are conducted in partnership with museums, galleries and similar stakeholders in the cultural sector. Based on a total of 68 projects, the survey remains incomplete but, even so, it indicates important trends and offers a knowledge base for future coordination and initiation of research initiatives, at least in a Danish context. Are similar trends to be found in the other Nordic countries?

A key element in advancing research quality on a national level is research training. In collaboration with the $\mathrm{PhD}$ school of the Faculty of Humanities at University of Southern Denmark, DCMR hosted its first international doctoral seminar, Museum Education Research, in March 2013 gathering 20 young scholars from seven different countries to a programme of master classes, presentations by junior faculty from the Nordic countries and keynote lectures by Lynn Dierking, Oregon State University, and François Mairesse, Université Sorbonne Nouvelle. A oneday doctoral course is planned for September 2013. For small research communities such as exist in Denmark, national coordination of research training, including courses, remains 
vital in order to retain diversity, volume and quality of output. This is particularly true in a situation where all doctoral training in Denmark is located at individual faculties, while, at the same time, a newly revised Museum Act, taking effect from 2013, aims at strengthening the formal competences of researchers affiliated to museums, including their acquisition of a $\mathrm{PhD}$ degree.

\section{ILLUMINATING INSIGHTS THROUGH RESEARCH COMMUNICATION}

DCMR is at pains to develop networks and partnerships among university and museum researchers. An important means to do so are a thematic seminar series initiated by the Centre and circulating between centre members across the country. Here, researchers from different institutional backgrounds present research results and exchange insights and experiences with the audience on themes ranging from 'the strategic museum' on to 'future acquisition and archiving' and 'the status of university museums'. The congregation of an upward of 60 people to the seminars - students, researchers, museum professionals, public servants and administrators - is a testimony to the widespread interest in cross-disciplinary knowledge exchange.

As part of the wider societal engagements, the Centre hosts an annual international conference preceded by a one-day satellite doctoral course. Changing Concepts of Museum Research was the theme for the 2012 conference, featuring, for instance, Dr. Ross Parry, University of Leicester, and Professor Brita Brenna, University of Oslo, while in 2013 the theme is Museum Limits? Relating Museums, Science and Experience Centres. As is the case with the seminar series, the conferences bring together delegates and lecturers from a diversity of institutional and disciplinary backgrounds to engage with particular thematic points of interest, just as our invited speakers from abroad offer welcome perspectives on domestic research issues.

\section{HOW ARE WE ORGANISED?}

As noted, DCMR started as a bottom-up initiative prompted by researchers who felt a need to reach beyond the assumed precariousness of museum research at Danish universities. Fortunately, the initiative was met with very positive institutional response by department heads sharing the wish to foster more robust modes of organisation and development through their annual memberships. A board of directors, encompassing one research representative from each department member, partakes in the strategic and operational development of the Centre, while its day-to-day business is conducted by the centre director assisted by a part-time secretary. At present, University of Southern Denmark hosts the centre director and secretariat, a task that circulates among member universities on a three-year basis. This is a 'lean' mode of organisation that, hopefully, facilitates administrative efficiency in combination with a sense of institutional ownership and responsibility.

\section{SYNERGIES IN MUSEUM RESEARCH}

Over the past decade, much has been made at institutional as well as policy levels about 'proper' definitions of research when it comes to museums, archives and libraries: do particular definitions of research applied differ from those found at universities? Or, do researchers working in these cultural sectors share with 
128 their university colleagues how research is practiced and advanced? These debates have often resulted in divisive polarities of little help to areas of research facing increasing financial challenges from strategic areas of high policy priority.

At DCMR we are keen to help foster an inclusive understanding of what museum research is and could be and to help strengthen interaction with the cultural sector as well as with Nordic and international partners based on a joint interest in having museum research become a robust base of museum development. While it is important to recognise that research based at museums is, indeed, organised differently than museum research carried out at universities - not least because collections and visitors play different roles as baselines of study in museums - it is equally important to acknowledge that different ramifications of research may offer useful synergies.

Since a legal change in 2003, Danish universities are obliged to engage with industry and society at large through knowledge exchange in addition to their 'traditional' functions of research and research-based education. This change has accelerated priorities of partnerships with public and, especially, private stakeholders; and DCMR is an example of the way in which universities can illuminate research resources for partners in the cultural sector, a visibility which may ease knowledge exchange and interaction.

Conversely, policy changes have hastened researchers at Danish museums, libraries and archives to obtain more formalised academic competences such as a $\mathrm{PhD}$ degree and to publish in peer-reviewed journals and books. So, the cultural sector is speeding up its adaptation of university norms, while the university sector is speeding up its knowledge exchange and partnership formation. All in all not a bad basis for a Centre at pains to address and help advance a holistic understanding of museum research and development.

\section{LITERATURE}

Drotner, Kirsten \& Schrøder, Kim C. (Eds.): $M u$ seum Communication and Social Media: The Connected Museum. Routledge: New York 2013.

Nowotny, Helga, Scott, Peter \& Gibbons, Michael: Re-thinking Science: Knowledge and the Public in an Age of Uncertainty. Polity Press: Cambridge 2001.

Skot-Hansen, Dorte: Museerne i den danske oplevelsesøkonomi: når oplysning bliver til oplevelse

[Museums in the Danish Experience Economy: When Enlightenment Turns to Entertainment]. Samfundslitteratur: Copenhagen 2008.

Villadsen, Rikke \& Drotner, Kirsten: Dansk museumsforskning: status og tendenser [Danish Museum Research: Status and Trends]. Danish Centre for Museum Research: Odense 2012. See: www.museumsforskning.dk

* Hans Dam Christensen, PhD, Research and PhD coordinator. Deputy-director of Danish Centre for Museum Research Royal School of Library and Information Science University of Copenhagen

E-mail:jbg621@iva.ku.dk

*Kirsten Drotner, dr.phil., Professor. Director of Danish Centre for Museum Research

Dept. for the Study of Culture - Media Studies University of Southern Denmark

E-mail: drotner@sdu.dk 